\title{
Optimization, Purification and Characterization of Phytase from Isolated Probiotic Pediococcus acidilactici BNS5B
}

\author{
Bhawna Sharma and Geeta Shukla* \\ Department of Microbiology, Panjab University, Chandigarh-160014, India \\ *Corresponding author
}

\section{A B S T R A C T}

Keywords

Plackett-Burman Design, Response Surface

Methodology, Ionexchange chromatography

Article Info

Accepted:

20 August 2019

Available Online:

10 September 2019
Microbial phytases are of immense importance due to their application in food/feed industry by enhancing the availability of essential minerals such as phosphorous, iron, calcium etc. required for normal human physiology and also have commercial and environment significance. Therefore, in present study an attempt was made to enhance the production of phytase from isolated probiotic Pediococcus acidilactici BNS5B by employing both one variable at a time approach and statistically based design of experiments such as Plackett-Burman and Response Surface Methodology. Interestingly, phytase production was enhanced 94 fold at an optimised condition of $0.8 \%$ galactose, $1.25 \%$ yeast extract, $1.25 \%$ beef extract and $1.25 \%$ ammonium sulphate. Further, the phytase enzyme was purified and had apparent molecular weight of $43 \mathrm{KDa}, \mathrm{pH}$ optima of 5.5 with $\mathrm{pH}$ stability in the range of 2.5-6.5, temperature optima of $40^{\circ} \mathrm{C}$ and retaining an activity of $76 \%$ at a temperature range of $20-80^{\circ} \mathrm{C}$ and followed normal Michael-Menten curve with the kinetic parameter $\mathrm{K}_{\mathrm{m}}$ and $\mathrm{V}_{\max }$ of $0.5455 \mathrm{mM}$ and $33.927 \mu \mathrm{mol} / \mathrm{min}$ respectively. Taken together, it is suggested that phytase from probiotic Pediococcus acidilactici BNS5B can be employed to enhance mineral bioavailability in food/feed industry, but needs to be correlated both experimentally and clinically.

\section{Introduction}

Plant based diet such as vegetables, cereals, legumes and oilseeds contain $80 \%$ of total phosphorous in the form of phytic acid-cation complexes, bound phosphorous being excreted in manure due to unavailability of phytate degrader in the gastrointestinal tract of monogastric animals (Ashraf et al., 2013). The undegraded phytate leads to phosphorous deficiency in animals, elevated levels of phosphorous in soil and eutrophication of water bodies and renders phytic acid as the anti-nutritive factor by decreasing the bioavailability cations such as iron, calcium, magnesium, phosphorous, zinc, iodine, etc (Madsen, 2019; Singh et al., 2013). Most of these cations are involved in various physiological functions as their deficiency may lead to conditions such as anemia, 
neurological disorders, immune disorders (Black et al., 2013; Christian and Stewart., 2010). The enzymatic degradation of organically bound phosphate by phosphohydrolases and phytases, reduces the need of feed supplementation with calcium phosphate resulting in reduced phosphorous excretion and environmental pollution (Almeida et al., 2013).

Phytases are used as feed supplement to manogastric animals for the reduction of phytate and have been isolated from various sources like plant, animals, bacteria, fungi for improving the nutritional quality of food and feed products (Rasul et al., 2019; Shah et al., 2017; Menezes-Blackburn et al., 2015). However, microbial phytases are more efficacious due to their substrate specificity, resistance to proteolysis and catalytic efficiency for animal nutrition, environment protection as well as for human health (Qvirist et al., 2017; Sreedevi and Reddy, 2013; Saravanamuthu, 2010). The various commercially available phytases have been produced synthetically from genetically modified organisms such as Quantum ${ }^{\mathrm{TM}}$ being produced from Escherichia coli, Natuphos ${ }^{\mathrm{TM}}$ from Aspergillus niger, Ronozyme from Peniophora lycii and Phyzyme is derived from yeast Schizosacchromyces pombe and are used for in-vitro degradation of livestock feed products (Menezes-Blackburn et al., 2015; Nam-Soon Oh and Man-Jin In, 2009). Since, recombinant phytases are costly and are under legal issues, thus the need of hour is that a phytase to be used as the feed additives should be more economical and effective in releasing phytate phosphorous in the digestive tract (Sreedevi and Reddy, 2013a). Therefore, an attempt was made to isolate an organism with phytase activity from the human microbiome as gut microbiota is the least explored source of microorganisms capable of producing enzymes of industrial importance (Feng et al., 2018; Haefner et al., 2005). In this context, we have isolated a phytase producing probiotic Pediococcus acidilactici BNS5B from neonatal feces with dephytinising ability on both food/feed products (Sharma and Shukla, communicated).

Due to the commercial importance of phytase and to enhance the yield of phytase being produced by isolated probiotic Pediococcus acidilactici BNS5B, different optimisation strategies have been employed (Qvirist et al., 2017). Therefore, designing an appropriate medium is of crucial importance because medium composition significantly affects the growth of organism vis-à-vis enzyme yield (Gao et al., 2009). However, the traditional one variable at a time technique used for optimisation is not only time consuming and employs number of experiments to determine the optimum levels but also misses the alternative effect between the nutrients (Kumar and Satynarayan, 2007). To overcome these problems Plackett- Burman (PlackettBurman, 1946) and Central Composite Design using Response Surface Methodology (RSM) was employed where levels can be easily evaluated. Therefore, in the present study physico-chemical parameters were optimised to design a medium for enhanced yield of phytase from isolated well characterized probiotic Pediococcus acidilactici BNS5B as well as to characterise the purified phytase.

\section{Materials and Methods}

\section{Bacterial strain}

Pediococcus acidilactici BNS5B (Accession No. MH916767) was grown and maintained in chemically defined medium (CDM). Briefly, media contained glucose $(1.5 \%)$, yeast extract $(1 \%)$, beef extract $(0.5 \%)$, peptone $(1 \%)$, sodium acetate (2.5\%), $\mathrm{FeSO}_{4}(0.001 \%)$, $\mathrm{MgSO}_{4} .7 \mathrm{H}_{2} \mathrm{O}(0.01 \%), \mathrm{CaCl}_{2} .2 \mathrm{H}_{2} \mathrm{O}(0.01 \%)$,

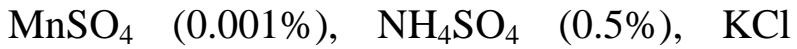
$(0.05 \%), \mathrm{NaCl}(0.01 \%)$, calcium phytate $(1 \%)$ 
and $\mathrm{pH} 6.5$ was inoculated, incubated at $37^{\circ} \mathrm{C}$ for $24 \mathrm{~h}$ for the production of enzyme phytase and was optimised to enhance the production of phytase.

\section{Phytase assay}

Activity of phytase produced by probiotic $P$. acidilactici BNS5B was assayed as per Raghavendra and Halami, 2009. Briefly, $100 \mu \mathrm{L}$ of the supernatant containing enzyme was mixed with $900 \mu \mathrm{L}$ of substrate $(2 \mathrm{mM}$ calcium phytate in sodium acetate-acetic acid buffer, $\mathrm{pH} 5.5$ ) and incubated $15 \mathrm{~min}$ at $37^{\circ} \mathrm{C}$ for catalytic reaction. The reaction was stopped by addition of $500 \mu \mathrm{L}$ trichloroacetic acid (10\%), followed by addition of $1 \mathrm{~mL}$ coloring reagent (prepared by mixing 1 volume of $2.5 \%$ ferrous sulphate to 4 volumes of $2.5 \%$ ammonium molybdate in $5.5 \%$ sulphuric acid) was added. The released inorganic phosphorous was measured spectrophotometrically at $700 \mathrm{~nm}$ as the phytase activity is the amount of enzyme liberating $1 \mu \mathrm{mol}$ of inorganic phosphate from calcium phytate under standard assay conditions (Nielsen et al., 2008).

Hyperproduction of phytase from $P$. acidilactici BNS5B in submerged fermentation (SmF)

The various physico-chemical factors were optimized for hyperproduction of phytase from probiotic $P$. acidilactici BNS5B employing both one variable at a time (OVAT) and statistical method (PlackettBurman and Response Surface Methodology) in submerged fermentation.

\section{Optimisation of phytase production in $\mathrm{SmF}$} by One-variable-at-a-time method (OVAT).

Various nutritional (carbon source, nitrogen source) and physical parameters (incubation time, incubation temperature, inoculum age, inoculum percentage, $\mathrm{pH}$, agitation) are known to affect the enzyme yield. Therefore, the optimisation of phytase was performed by varying the nutritional and physical parameters one at a time keeping other variables constant in production media. The optimized condition in each step was taken as constant for subsequent steps and the phytase activity was assessed after every optimisation step as described above.

\section{Incubation time}

To assess the effect of time on phytase production, the production medium was inoculated with $1 \%$ inoculum of $18 \mathrm{~h}$ old $\log$ phase culture and incubated at $37^{\circ} \mathrm{C}$ for $120 \mathrm{~h}$. After every $24 \mathrm{~h}$ the culture was cold centrifuged at $7826 \mathrm{~g}$ and the cell free supernatant was analyzed for phytase activity.

\section{Inoculum age and Inoculums density}

The inoculum age was optimized by inoculating the production medium with $1 \%$ inoculum of different age $(12,24,48,72$ and $120 \mathrm{~h}$ ) and incubated at $37^{\circ} \mathrm{C}$ for $72 \mathrm{~h}$.

Thereafter, the phytase activity was assessed in the cell free supernatant. However for inoculum size, medium was inoculated with different concentration (1\%-5\%) of $24 \mathrm{~h}$ culture by all other variables in optimum conditions. After incubation the cell free supernatant was obtained and analyzed for phytase activity.

\section{Effect of different carbon sources}

Effect of different carbon sources (Glucose, Galactose, Sucrose, Lactose, Mannose, Xylose, Arabinose) was estimated by replacing glucose in the production medium with $1 \%$ respective sugar and incubating at $37^{\circ} \mathrm{C}$ for $72 \mathrm{~h}$, cold centrifuged and cell free supernatant was analyzed for phytase activity. 
Effect of different concentration of galactose

Concentration of galactose was varied from 0 to $5 \%$ in the production medium and incubated at $37^{\circ} \mathrm{C}$ for $72 \mathrm{~h}$. Thereafter, the culture was cold centrifuged and phytase activity was assessed in the supernatant.

\section{Production pH}

To determine the effect of $\mathrm{pH}$ on the production of phytase, the $\mathrm{pH}$ of the production medium was varied from 3.5 to 7.5 with $1 \mathrm{M} \mathrm{HCl}$ and $1 \mathrm{~N} \mathrm{NaOH}$. The medium was then assessed for phytase production after $72 \mathrm{~h}$ at $37^{\circ} \mathrm{C}$ keeping all other conditions constant.

\section{Effect of Incubation Temperature}

To find out the optimal incubation temperature for maximum phytase production, the medium was inoculated with $1 \%$ inoculum and incubated at various temperatures i.e. $27^{\circ} \mathrm{C}$, $37^{\circ} \mathrm{C}, 47^{\circ} \mathrm{C}, 57^{\circ} \mathrm{C}$ and $67^{\circ} \mathrm{C}$ for $72 \mathrm{~h}$ while other conditions were kept optimum and phytase activity was monitored.

\section{Effect of different nitrogen sources}

The effect of nitrogen source was determined by replacing ammonium sulphate in the production medium with $1 \%$ of different nitrogen sources (Beef extract, Yeast Extract, Peptone, Urea, Ammonium sulphate, Potassium nitrate, Sodium nitrite, Ammonium ferricitrate).

\section{Optimisation of phytase production in $\mathrm{SmF}$} by statistical method.

Selection of significant factors by PlackettBurman design

On the basis of OVAT, the 11 variables i.e. Galactose, Beef Extract, Yeast extract,
Proteose Peptone, Ammonium sulphate, Inoculum density, Manganese sulphate, Magnesium sulphate, Potassium chloride, Sodium chloride and Calcium chloride were screened using Plackett- Burman Design (Design expert 11.03, Stat-Ease Inc., Minneapolis, USA at two levels (high and low; +1 and -1$)$ for the preliminary screening of significant cultural parameters that may further affect the production of enzyme phytase from P. acidilactici BNS5B (Table 1). Factors were analysed using normal probability plot or pareto-chart of model where factors showing maximum positive effect were selected for further optimisation using central composite design of response surface methodology.

Response surface methodology using Central composite design

The variables affecting positively on the enzyme production were further optimised by central composite design (CCD) using design expert software 11.0.3. The four most significant factors i.e. Galactose, Ammonium sulphate, Beef Extract and Yeast Extract were optimized at five different levels $(-2,-1,0,+1$, +2 ) in an experimental plan of 30 trials keeping other factors constant. A multiple regression analysis of the data was carried out for obtaining an empirical model that relates the response measured to the independent variables. The following equation explained the behaviour of the system and was used to construct 3D plots (Eq. 1).

$\mathrm{Y}=\beta_{\mathrm{o}}+\Sigma \beta_{\mathrm{i}} \mathrm{X}_{\mathrm{i}}+\Sigma \beta_{\mathrm{ii}} \mathrm{X}_{\mathrm{i}}^{2}+\Sigma \beta_{\mathrm{ij}} \mathrm{X}_{\mathrm{i}} \mathrm{X}_{\mathrm{j}}$

(Eq. 1)

Where $\mathrm{Y}$ is predicted response (Phytase activity $\mathrm{U} / \mathrm{mL}$ ), $\beta_{\mathrm{O}} \quad$ is constant, $\beta_{\mathrm{i}}$ is coefficient of linear effect, $B_{\mathrm{ii}}$ is coefficient of quadratic effect, $\beta_{\mathrm{ij}}$ is coefficient of interaction effect. 
The 3D and counter plots generated with the statistical software were employed to analyse the trend of phytase activity and the interactive effect of the significant variables on the activity response. The resulting model was analysed using ANOVA and the significance of each coefficient was determined by $\mathrm{p}$ and $\mathrm{f}$ value.

\section{Validation of the Experimental model}

The validation of the statistical model was performed using the optimal conditions predicted by the model and response (enzyme yield) was measured by phytase assay and compared with the predicted value. Each experiment was performed in triplicates.

\section{Purification and characterization of enzyme phytase from $P$. acidilactici BNS5B}

The phytase from the probiotic strain was purified using standard protein purification protocol. Optimized production media was inoculated with $1 \%$ inoculum of $24 \mathrm{~h}$ old MRS broth culture and incubated for $72 \mathrm{~h}$ at $37^{\circ} \mathrm{C}$. The crude enzyme was obtained after cold centrifugation of $15 \mathrm{~min}$ at $9000 \mathrm{~g}$. The cell free supernatant obtained was employed for purification of extracellular enzyme.

\section{Enzyme purification}

The cell free supernatant was filtered through a $0.45 \mu \mathrm{m}$ pore size filter and then the equal volumes of $70 \%$ ethanol was added to the filtrate and incubated overnight at $-20^{\circ} \mathrm{C}$. After ethanol precipitation, extracellular enzyme and alcohol was separated by cold centrifugation $(9000 \mathrm{~g}$ for $15 \mathrm{~min}$ ). The concentrated extracellular enzyme was suspended in $0.1 \mathrm{M}$ sodium acetate-acetic acid buffer, $\mathrm{pH} 5.5$, and a volume of $1 \mathrm{~mL}$ was loaded onto a DEAE- Cellulose ion-exchange column. The fractions were eluted with linear gradient of 0 to $0.5 \mathrm{M} \mathrm{NaCl}$ in $0.1 \mathrm{M}$ sodium acetate- acetic acid buffer ( $\mathrm{pH} 5.5)$ at a flow rate of $1 \mathrm{ml} / \mathrm{min}$. The eluted fractions were assayed for protein at $280 \mathrm{~nm}$ and phytase activity. The phytase active fractions were pooled and dialyzed against $10 \mathrm{mM}$ sodium acetate acetic acid buffer ( $\mathrm{pH} 5.5)$ and stored at $-20^{\circ} \mathrm{C}$ for further characterization. The protein content was estimated by Lowry's method at each purification step so as to assess specific activity, fold purification and yield percentage of enzyme (Parhamfar et al., 2015).

\section{Molecular mass determination}

The enzyme purified at each step was analyzed by SDS-PAGE (Laemmli, 1970). The molecular weight of the purified phytase was determined with the BLUeye Prestained protein ladder with wide range of 11 to 245 KDa.

\section{Characterization of purified phytase}

The purified phytase enzyme was characterized for $\mathrm{pH}$ optima, temperature optima, temperature stability and kinetic properties

\section{pH optima and stability}

The purified enzyme was assessed for the optimum $\mathrm{pH}$ by measuring the enzyme activity at different $\mathrm{pH}$ (2.5-8.5) using Glycine- $\mathrm{HCl}$ (2.5), Sodium acetate-Acetic acid (3.5-6.5) and Glycine- $\mathrm{NaOH}$ (7.5-8.5) buffers. The stability was assessed by preincubating the enzyme in buffer for one hour and the estimating the residual activity at optimum $\mathrm{pH}$ under standard assay conditions $\left(37^{\circ} \mathrm{C}, 15 \mathrm{~min}\right)$.

\section{Temperature optima and stability}

The optimum temperature of purified enzyme was determined at different temperature (20 to $70^{\circ} \mathrm{C}$ ) and thermal stability was determined by 
pre-incubating the enzyme at different temperature for 30 min followed by measuring the enzyme activity under standard conditions at optimized $\mathrm{pH}$.

\section{Effect of metal ions on purified phytase enzyme activity}

The effect of metal ions was determined by measuring phytase activity in the presence of metal ions $\left(\mathrm{Cu}^{2+}, \mathrm{Mg}^{2+}, \mathrm{Fe}^{2+}, \mathrm{Zn}^{2+}, \mathrm{Ca}^{2+}\right.$, $\mathrm{Mn}^{2+}$ ) at concentration of $0.5 \mathrm{mM}$ and $1 \mathrm{mM}$. To assess the effect $10 \mu \mathrm{L}$ of purified phytase was incubated with the metal ion solution at $37^{\circ} \mathrm{C}$ for $15 \mathrm{~min}$. Thereafter, the phytase activity at $40^{\circ} \mathrm{C}$ for $15 \mathrm{~min}$ was assessed and the enzyme without metal treatment was used as control.

\section{Substrate specificity and Kinetic parameters}

The substrate specificity of phytase was tested with $2 \mathrm{mM}$ concentration of sodium phytate, $\mathrm{p}$ nitrophenyl phosphate, sodium pyrophosphate and calcium phytate in $0.1 \mathrm{M}$ sodium acetate acetic acid buffer ( $\mathrm{pH}$ 5.5). The kinetic parameters of enzyme were studied for the substrate with maximum specificity.

The Michaelis-Menten constant $\left(\mathrm{K}_{\mathrm{m}}\right)$ and the maximum attainable velocity $\left(\mathrm{V}_{\max }\right)$ of phytase at different concentrations of sodium phytate $(0.5 \mathrm{mM}$ to $5 \mathrm{mM})$ was determined using Lineweaver- Burke plot and applying Michaelis-Menten equation (Eq. 2)

$\frac{1}{V_{s}}=\left(\frac{\mathrm{Km}}{V_{\max }}\right)\left(\frac{1}{[\mathrm{~s}]}\right)+\frac{1}{\mathrm{~V}_{\max }}$

Where $\mathrm{V}_{\text {。 }}$ is initial velocity and $[\mathrm{S}]$ is the substrate concentration

The phytase activity was measured at $40^{\circ} \mathrm{C}$ for 15 min by the standard enzyme assay. All the experiments were performed in triplicates, and results show the mean values of the activities.

\section{Statistical analysis}

All the experiments were repeated in triplicates and the results are expressed as mean \pm standard deviation.

\section{Results and Discussion}

Lactic acid bacteria are not naturally optimized for maximal production of biotechnologically important compounds, therefore it is of significant important to optimize nutritional and physical conditions with regard to desired end products (Wood and Holzapfel, 1995).

A variety of nutritional (carbon source, nitrogen source) and physical parameters (incubation time, incubation temperature, inoculum age, inoculum percentage, $\mathrm{pH}$, agitation) were optimised by conventional "one variable at a time" approach. The significant factors were then further optimised by statistical software package 'Design expert 11.1, Stat-Ease Inc., Minneapolis, USA'.

Effect of incubation time on phytase production

To assess the time course for enzyme production by $P$. acidilactici BNS5B, the medium was incubated upto $120 \mathrm{~h}$ and maximum phytase production was found after $72 \mathrm{~h}(0.33 \mathrm{U} / \mathrm{mL})$. Thereafter, phytase activity started declining due to catabolic repression or reduction in nutrient availability (Singh and Satyanarayan, 2006).

\section{Inoculum age and Inoculums density}

To investigate the optimum inoculum age and density for phytase production, inoculum of different ages (12, 24, 48, 72 and $120 \mathrm{~h}$ ) was employed and found to have maximum 
phytase activity $(0.42 \mathrm{U} / \mathrm{mL})$ with $24 \mathrm{~h}$ inoculum of $3 \% \mathrm{v} / \mathrm{v}$ density.

\section{Effect of different carbon sources and its} concentration

The phytase production was assessed with different carbon sources i.e. Glucose, Galactose, Sucrose, Lactose, Mannose, Xylose, Arabinose and was found that galactose at a concentration of $0.5 \%$ exhibited maximum activity of $0.72 \mathrm{U} / \mathrm{mL}$.

\section{Production pH}

To assess the effect of $\mathrm{pH}$ on phytase activity, medium with different $\mathrm{pH}$ (3.5 to 7.5) was employed and maximum phytase yield of $0.82 \mathrm{U} / \mathrm{mL}$ was obtained at $\mathrm{pH} 5.5$. This may be due to increase in $\mathrm{pH}$ that affects the active site resulting into decreased enzyme activity vis-a-vis enzyme-substrate complex formation (Roy et al., 2012).

\section{Effect of Incubation Temperature}

The phytase was produced at all the temperatures but maximum activity of $1.32 \mathrm{U} / \mathrm{mL}$ was obtained at $37^{\circ} \mathrm{C}$. As production of enzyme depends on the growth of microorganisms, since the optimum temperature for the growth of most organism lies in the range of $25^{\circ} \mathrm{C}-37^{\circ} \mathrm{C}$, resulting into enhanced enzyme production (Tungala et al., 2013).

\section{Effect of different nitrogen sources}

Since, LAB have limited capacity to synthesize amino acids from inorganic nitrogen source thereby to assess the optimum nitrogen source combination of both organic (Yeast extract, beef extract and peptone, urea) and inorganic nitrogen source (Ammonium sulphate, Potassium nitrate, Sodium nitrite, Ammonium Ferricitrate) was analysed. It was found that maximum phytase activity $(1.54 \mathrm{U} / \mathrm{mL})$ was observed with the combination of both organic $(1 \%$ of Yeast extract, $1 \%$ beef extract and $1 \%$ peptone) and inorganic nitrogen source $(1 \%$ ammonium sulphate) compared with organic $(0.44 \mathrm{U} / \mathrm{mL})$ and inorganic $(0.57 \mathrm{U} / \mathrm{mL})$ sources used alone (Fig. 1a,1b,1c). Therefore, it is crucial to include balanced amounts of yeast extract, beef extract and peptone in LAB culture media to ensure suitable level of growth and better functionality (Hayek and Ibrahim, 2013).

\section{Selection of significant factors by Plackett- Burman design}

The influence of 11 parameters i.e. Galactose, Beef Extract, Yeast extract, Proteose Peptone, Ammonium sulphate, Inoculum density, Manganese sulphate, Magnesium sulphate, Potassium chloride, Sodium chloride and Calcium chloride on phytase production was assessed in 12 runs using Plackett- Burman Design. The Length of columns in pareto chart represented the significance of studied parameters on enzyme activity (Fig. 2) where 4 factors (Galactose, Ammonium sulphate, Beef extract, Yeast extract) were found to have positive effect and were selected for further optimization using Central Composite Design (CCD) of Response surface methodology.

\section{Optimisation using Response Surface Methodology}

RSM using Central Composite Design (CCD) was employed to optimize and understand the interaction between 4 selected variables i.e. galactose, ammonium sulphate, beef extract and yeast extract in an experiments of 30 runs.

The coded levels of variable and experimental and predicted results of 30 runs for phytase activity are shown in Table 2. 
The results were analyzed by ANOVA (Table 3) and the second order regression equation was obtained which showed phytase activity as a function of galactose, ammonium sulphate, beef extract and yeast extract which can be predicted in terms of coded factors as:

$\mathrm{Y}=+\mathbf{5 4 . 0 0}+\mathbf{0 . 2 4 2 1} \mathrm{A}+\mathbf{0 . 0 8 7 9} \mathrm{B}+\mathbf{0 . 2 9 2 1} \mathrm{C}$ $+0.1971 \mathrm{D}-\mathbf{0 . 8 7 4 4} \mathrm{AB}+\mathbf{0 . 7 1 0 6} \mathrm{AC}+\mathbf{1 . 6 8}$ $\mathrm{AD}+1.13 \mathrm{BC}+0.6644 \mathrm{BD}-1.28 \mathrm{CD}-2.13 \mathrm{~A}^{2}$ $-1.69 B^{2}-1.30 C^{2}-1.33 D^{2}$

Where $\mathrm{Y}$ is phytase $(\mathrm{U} / \mathrm{mL}), \mathrm{A}$ is galactose $(\%), \mathrm{B}$ is ammonium sulphate $(\%), \mathrm{C}$ is beef extract $(\%)$ and $\mathrm{D}$ is yeast extract (\%).

The "lack of fit" value of 0.8740 and $p$ value of $<0.001$ indicated the model to be highly significant. The coefficient of determination $\left(\mathrm{R}^{2}\right)$ was 0.9663 which implies data variability in the response of $96.63 \%$. The coefficient correlation depicted by predicted $\mathrm{R}^{2}$ was $88.32 \%$ which suggests good agreement between predicted and experimental values of phytase production. The model showed $\mathrm{AB}$, $\mathrm{AC}, \mathrm{AD}, \mathrm{BC}, \mathrm{CD}, \mathrm{A}^{2}, \mathrm{~B}^{2}, \mathrm{C}^{2}$ and $\mathrm{D}^{2}$ to be significant. The 3D response surface plots showed optimal levels from the peak and non linear interaction between the variables for phytase production from shape of the curve and the elliptical counter plots indicate that the interaction between related variables are significant (Fig 3). All these factors depict that model could be used for prediction of phytase yield under given ranges.

The model predicted that maximum phytase production $(55.53 \mathrm{U} / \mathrm{mL})$ was obtained with $0.8 \mathrm{~g}$ galactose, $1.25 \mathrm{~g}$ each of yeast extract, beef extract and ammonium sulphate per $100 \mathrm{~g}$ after an incubation of $72 \mathrm{~h}$ at $37^{\circ} \mathrm{C}$ under static condition. The model was validated as phytase activity for optimum medium was in close agreement with predicted value. The phytase production under un-optimized conditions was $0.59 \mathrm{U} / \mathrm{mL}$ which increased to $55.53 \mathrm{U} / \mathrm{mL}$ resulting in approximately 94 fold increase.

\section{Purification of enzyme phytase from Pediococcus acidilactici BNS5B}

The phytase activity was eluted as a single sharp peak from ion- exchange column after application of the gradient (Fig. 4). A summary of the purification scheme is given in Table4. A 23 fold purification of the phytase was achieved with a recovery of $47.8 \%$ and enzyme exhibited an activity of about $66.5 \mathrm{U} / \mathrm{mg}$.

Table.1 Experimental range and 5 levels of independent test variables used in Central Composite Design for phytase production from Pediococcus acidilactici BNS5B

\begin{tabular}{|l|l|c|c|c|c|c|c|}
\hline Code & Factor & Units & \multicolumn{5}{|c|}{ LEVELS } \\
\cline { 4 - 8 } & & & $-\mathbf{2}$ & $\mathbf{- 1}$ & $\mathbf{0}$ & $\mathbf{+ 1}$ & $\mathbf{+ 2}$ \\
\hline $\mathbf{A}$ & Galactose & $\%$ & 0.4000 & 0.60 & 0.8000 & 1.00 & 1.20 \\
\hline $\mathbf{B}$ & $\begin{array}{l}\text { Ammonium } \\
\text { sulphate }\end{array}$ & $\%$ & 0.7500 & 1.00 & 1.25 & 1.50 & 1.75 \\
\hline $\mathbf{C}$ & Beef Extract & $\%$ & 0.7500 & 1.00 & 1.25 & 1.50 & 1.75 \\
\hline $\mathbf{D}$ & Yeast Extract & $\%$ & 0.7500 & 1.00 & 1.25 & 1.50 & 1.75 \\
\hline
\end{tabular}


Table.2 Experimental Design and result of Central Composite Design of Response Surface methodology.

\begin{tabular}{|c|c|c|c|c|c|c|c|}
\hline Run Order & $\begin{array}{c}\text { Galactose } \\
(\%)\end{array}$ & $\begin{array}{c}\text { Ammonium sulphate } \\
(\%)\end{array}$ & Beef Extract (\%) & $\begin{array}{c}\text { Yeast Extract } \\
(\%)\end{array}$ & $\begin{array}{c}\text { Experimental } \\
\text { Value }\end{array}$ & $\begin{array}{l}\text { Predicted } \\
\text { Value }\end{array}$ & Residual \\
\hline 1 & 0 & 0 & 0 & 0 & 53.32 & 54.00 & -0.6783 \\
\hline 2 & +1 & +1 & -1 & +1 & 48.43 & 48.68 & -0.2533 \\
\hline 3 & -1 & -1 & +1 & 1 & 48.81 & 48.21 & 0.5967 \\
\hline 4 & 0 & +2 & 0 & 0 & 47.56 & 47.41 & 0.1471 \\
\hline 5 & -1 & -1 & -1 & +1 & 47.40 & 47.01 & 0.3867 \\
\hline 6 & +1 & -1 & -1 & +1 & 51.21 & 51.18 & 0.0312 \\
\hline 7 & -1 & +1 & -1 & +1 & 47.24 & 48.02 & -0.7754 \\
\hline 8 & -2 & 0 & 0 & 0 & 44.85 & 44.98 & -0.1279 \\
\hline 9 & 0 & 0 & 0 & 0 & 52.31 & 54.00 & -1.69 \\
\hline 10 & +1 & +1 & +1 & -1 & 47.82 & 47.86 & -0.0433 \\
\hline 11 & 0 & 0 & -2 & 0 & 48.56 & 48.21 & 0.3521 \\
\hline 12 & 0 & 0 & 0 & 0 & 54.76 & 54.00 & 0.7617 \\
\hline 13 & -1 & -1 & -1 & -1 & 48.66 & 48.75 & -0.0904 \\
\hline 14 & +1 & -1 & -1 & -1 & 45.37 & 46.21 & -0.8383 \\
\hline 15 & 0 & 0 & 0 & 0 & 53.90 & 54.00 & -0.0983 \\
\hline 16 & +1 & +1 & -1 & -1 & 41.33 & 41.06 & 0.2746 \\
\hline 17 & -1 & +1 & -1 & -1 & 47.35 & 47.10 & 0.2550 \\
\hline 18 & +2 & 0 & 0 & 0 & 46.38 & 45.95 & 0.4337 \\
\hline 19 & 0 & -2 & 0 & 0 & 47.22 & 47.06 & 0.1587 \\
\hline 20 & -1 & +1 & +1 & +1 & 48.06 & 46.88 & 1.18 \\
\hline 21 & 0 & 0 & +2 & 0 & 49.33 & 49.38 & -0.0463 \\
\hline 22 & +1 & -1 & +1 & -1 & 48.64 & 48.51 & 0.1262 \\
\hline 23 & +1 & +1 & +1 & +1 & 49.83 & 50.39 & -0.5588 \\
\hline 24 & 0 & 0 & 0 & 0 & 55.53 & 54.00 & 1.53 \\
\hline 25 & 0 & 0 & 0 & -2 & 48.33 & 48.28 & 0.0471 \\
\hline 26 & 0 & 0 & 0 & 0 & 54.17 & 54.00 & 0.1717 \\
\hline 27 & -1 & +1 & +1 & -1 & 50.38 & 51.06 & -0.6804 \\
\hline 28 & -1 & -1 & +1 & +1 & 40.45 & 41.37 & -0.9237 \\
\hline 29 & +1 & -1 & +1 & +1 & 48.47 & 48.38 & 0.0883 \\
\hline 30 & 0 & 0 & 0 & +2 & 49.33 & 49.07 & 0.2587 \\
\hline
\end{tabular}

Std. Dev. $=0.8868$, Mean $=48.83$, C.V. $\%=1.82, \mathrm{R}^{2}=0.9663$, Adjusted $\mathrm{R}^{2}=0.9348$, Predicted $\mathrm{R}^{2}=0.8832$, Adeq Precision $=20.6405$ 
Table.3 Analysis of Variance and regression analysis for phytase production by Pediococcus acidilactici BNS5B by CCD.

\begin{tabular}{|c|c|c|c|c|c|c|}
\hline Source & Sum of Squares & df & Mean Square & F-value & p-value & \\
\hline Model & 337.86 & 14 & 24.13 & 30.69 & $<0.0001$ & significant \\
\hline A-Galactose & 1.41 & 1 & 1.41 & 1.79 & 0.2010 & \\
\hline B-Ammonium sulfate & 0.1855 & 1 & 0.1855 & 0.2359 & 0.6342 & \\
\hline C-Beef & 2.05 & 1 & 2.05 & 2.60 & 0.1275 & \\
\hline D-Yeast Extract & 0.9322 & 1 & 0.9322 & 1.19 & 0.2934 & \\
\hline $\mathrm{AB}$ & 12.23 & 1 & 12.23 & 15.55 & 0.0013 & \\
\hline $\mathrm{AC}$ & 8.08 & 1 & 8.08 & 10.27 & 0.0059 & \\
\hline $\mathrm{AD}$ & 44.99 & 1 & 44.99 & 57.21 & $<0.0001$ & \\
\hline $\mathrm{BC}$ & 20.27 & 1 & 20.27 & 25.78 & 0.0001 & \\
\hline $\mathrm{BD}$ & 7.06 & 1 & 7.06 & 8.98 & 0.0090 & \\
\hline $\mathrm{CD}$ & 26.04 & 1 & 26.04 & 33.11 & $<0.0001$ & \\
\hline $\mathrm{A}^{2}$ & 124.92 & 1 & 124.92 & 158.84 & $<0.0001$ & \\
\hline $\mathrm{B}^{2}$ & 78.37 & 1 & 78.37 & 99.65 & $<0.0001$ & \\
\hline $\mathrm{C}^{2}$ & 46.47 & 1 & 46.47 & 59.09 & $<0.0001$ & \\
\hline $\mathrm{D}^{2}$ & 48.54 & 1 & 48.54 & 61.72 & $<0.0001$ & \\
\hline Residual & 11.80 & 15 & 0.7864 & & & \\
\hline Lack of Fit & 5.52 & 10 & 0.5520 & 0.4398 & 0.8740 & not significant \\
\hline Pure Error & 6.28 & 5 & 1.26 & & & \\
\hline Cor Total & 349.66 & 29 & & & & \\
\hline
\end{tabular}


Table.4 Purification and yield of phytase from Pediococcus acidilactici BNS5B

\begin{tabular}{|l|l|l|l|l|l|}
\hline & $\begin{array}{l}\text { Total protein } \\
(\mathbf{m g})\end{array}$ & $\begin{array}{l}\text { Total activity } \\
(\mathbf{U})\end{array}$ & $\begin{array}{l}\text { Specific activity } \\
(\mathbf{U} / \mathbf{m g})\end{array}$ & Purification fold & Yield (\%) \\
\hline Crude supernatant & 1590 & 4580 & 2.88 & 1 & 100 \\
\hline Ethanol precipitated & 379 & 3583 & 9.45 & 3.28 & 78.2 \\
\hline $\begin{array}{l}\text { DEAE- cellulose ion } \\
\text { exchange } \\
\text { chromatography }\end{array}$ & 33 & 2195 & 66.51 & 23.09 & 47.8 \\
\hline
\end{tabular}

Table.5 Effect of metal ions on the activity of Pediococcus acidilactici BNS5B phytase

\begin{tabular}{|l|l|l|}
\hline \multirow{2}{*}{ Metal ions } & \multicolumn{2}{|l|}{ Relative activity $(\%)$} \\
\cline { 2 - 3 } Control & $0.5 \mathrm{mM}$ & $1 \mathrm{mM}$ \\
\hline $\mathrm{Cu}^{2+}$ & 100 & 100 \\
\hline $\mathrm{Mg}^{2+}$ & 57.43 & 55.57 \\
\hline $\mathrm{Fe}^{2+}$ & 62.7 & 54.51 \\
\hline $\mathrm{Zn}^{2+}$ & 60.95 & 54.14 \\
\hline $\mathrm{Ca}^{2+}$ & 58.67 & 54.6 \\
\hline $\mathrm{Mn}^{2+}$ & 59.8 & 56.61 \\
\hline
\end{tabular}

Phytase activity with no metal ions (Control) was considered $100 \%$. 
Fig.1 Effect of different nitrogen sources on the phytase production: a) Organic sources (1\% each); b) Inorganic sources; c) Combination of organic (Beef extract +Yeast extract + peptone) and inorganic (Urea, Potassium nitrate, Ammonium acetate, Ammonium sulphate).

a)

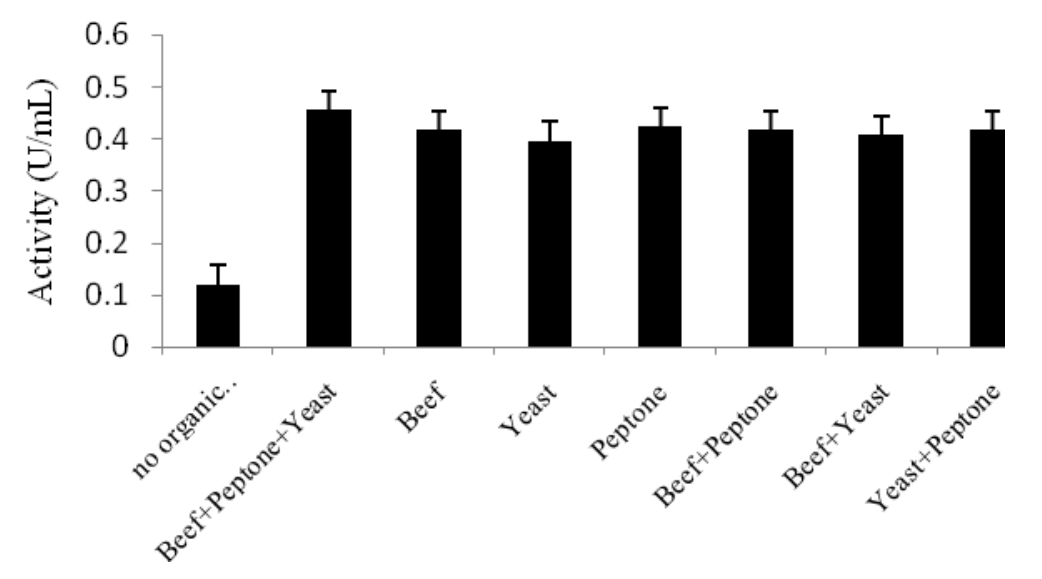

b)

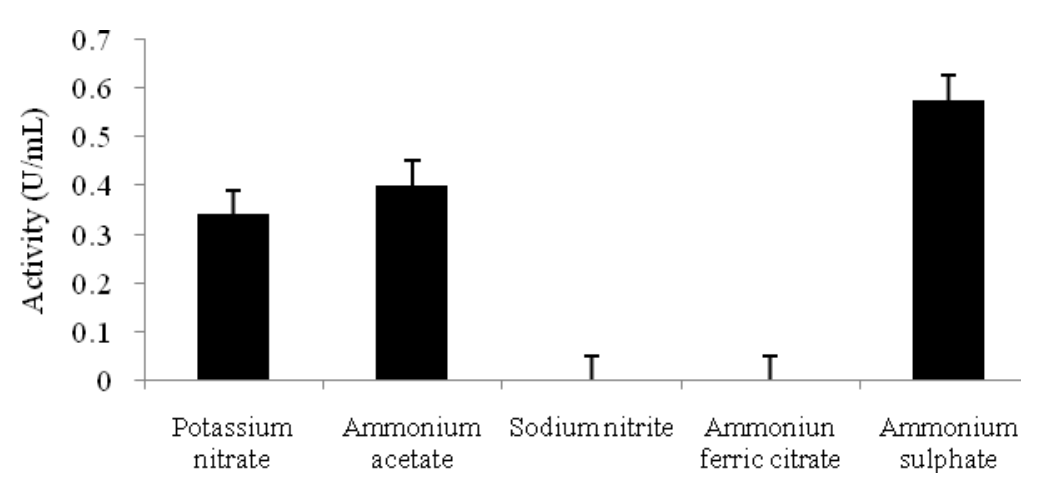

c)

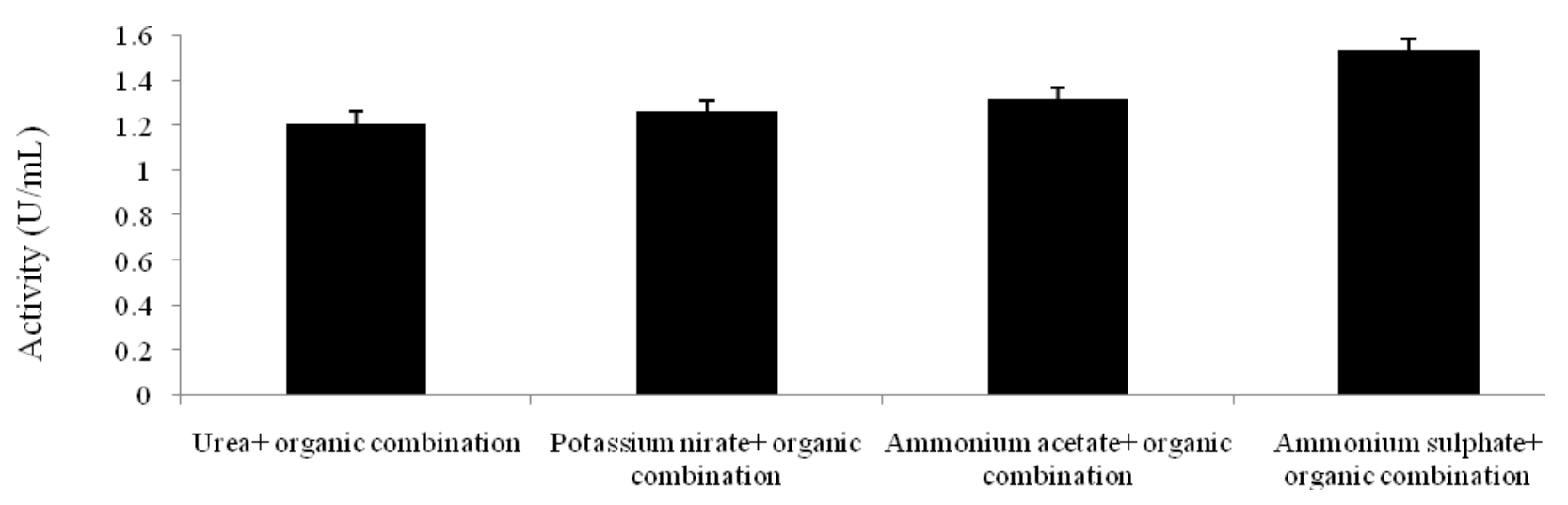


Fig.2 Pareto chart showing effect of different parameters in the Plackett-Burman design for phytase production from Pediococcus acidilactici BNS5B

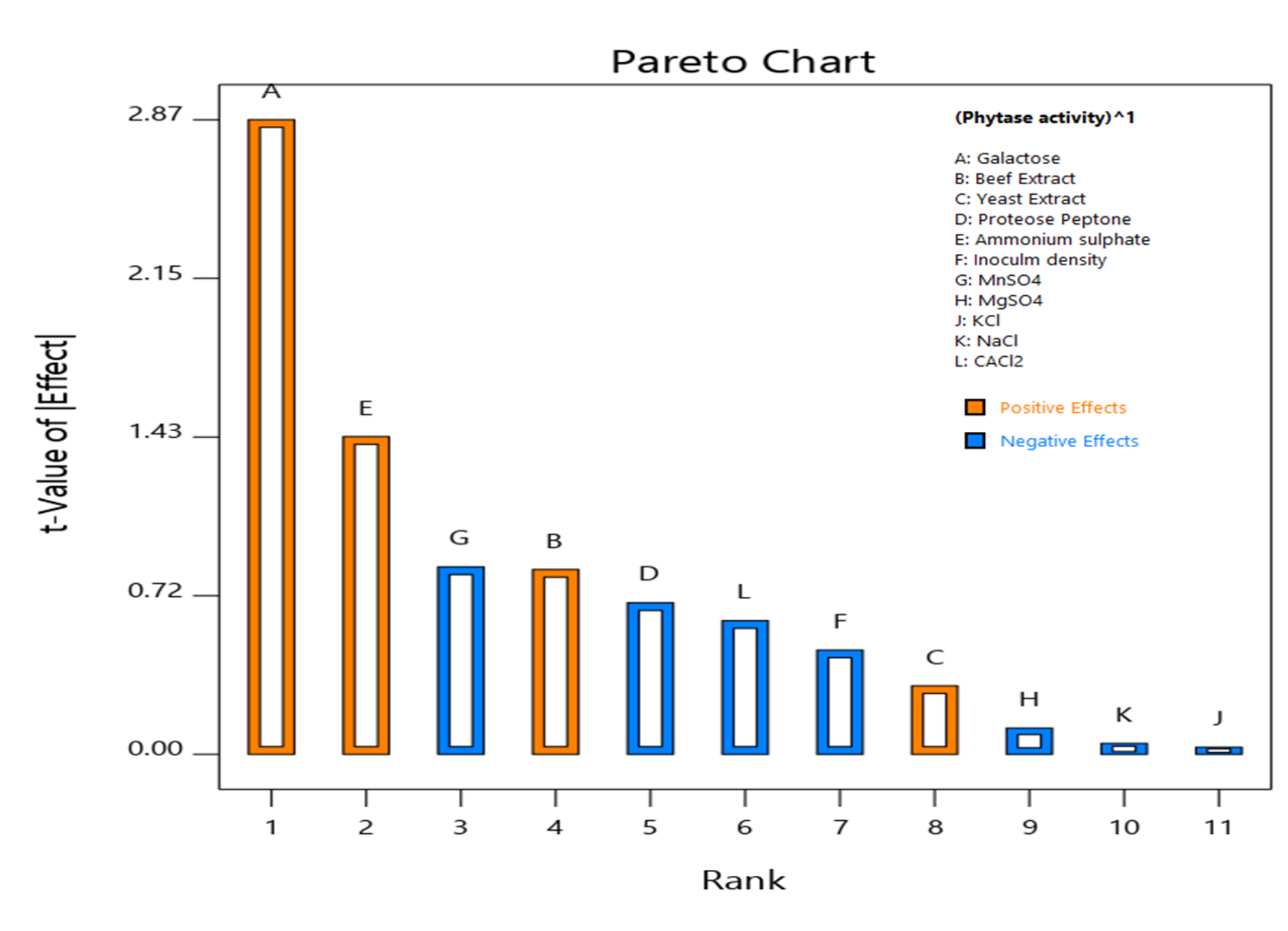


Fig.3 3D plots and contour plots of interaction between 2 variables when the third was kept at its optimum value: A) Ammonium sulphate and Galactose; B) Beef extract and Galactose; C) Yeast extract and Galactose; D) Beef extract and Ammonium sulphate.

A)

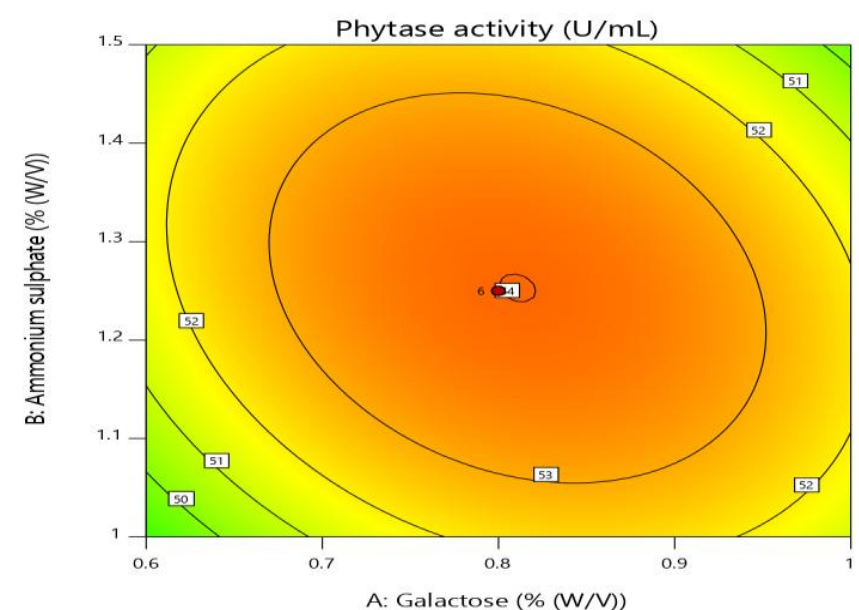

B)

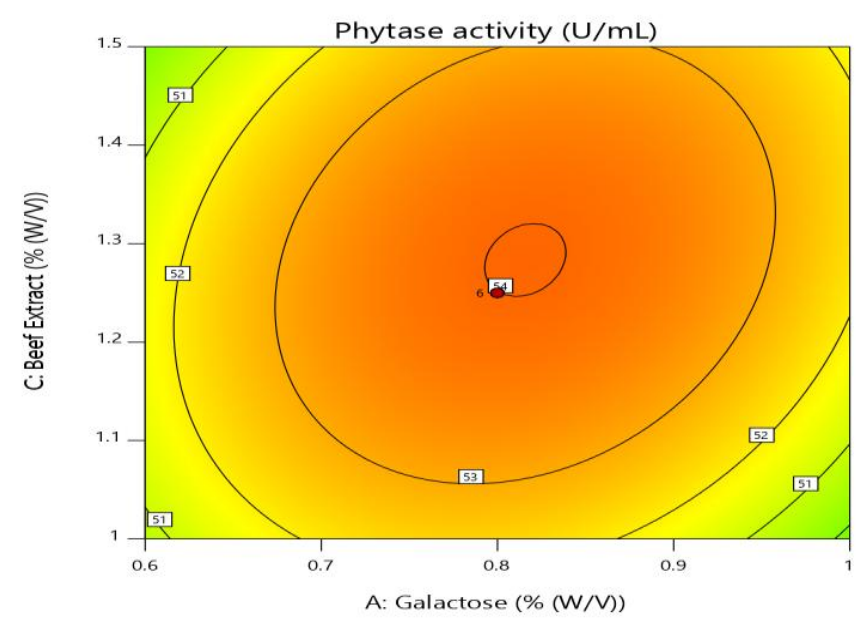

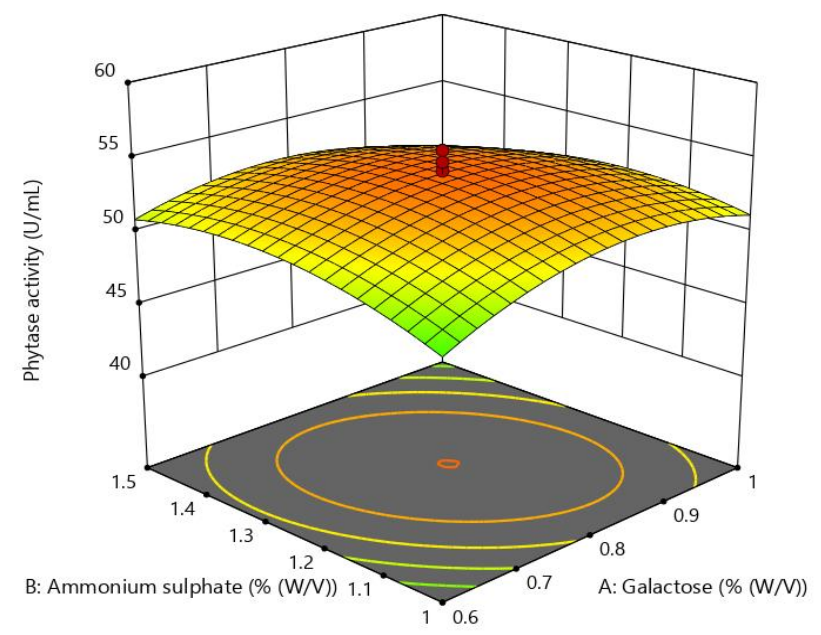

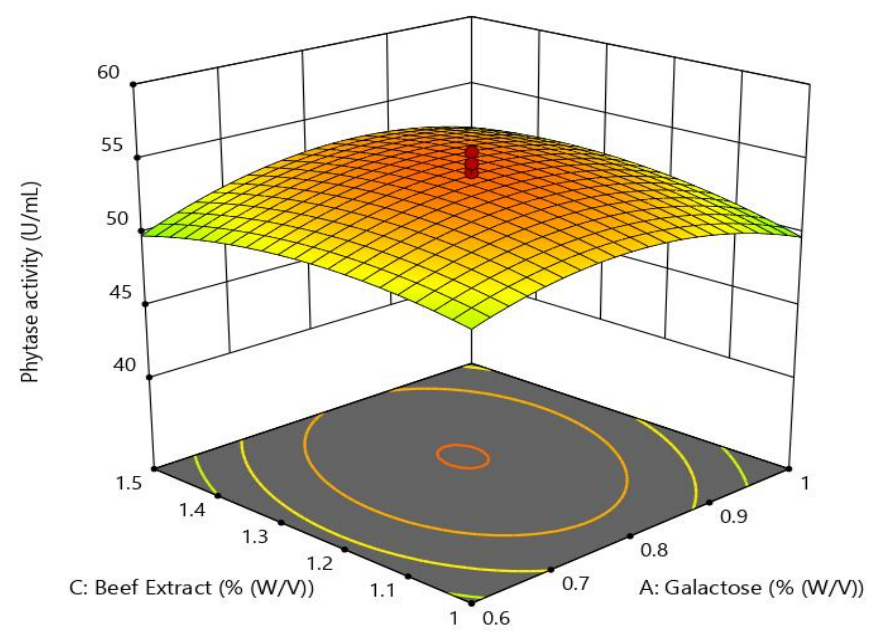




\section{Int.J.Curr.Microbiol.App.Sci (2019) 8(9): 2060-2081}

C)

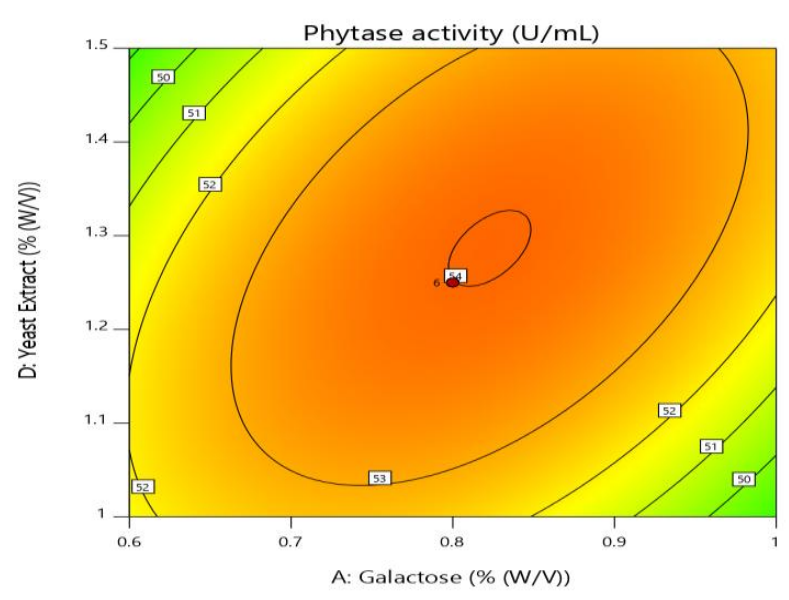

D)

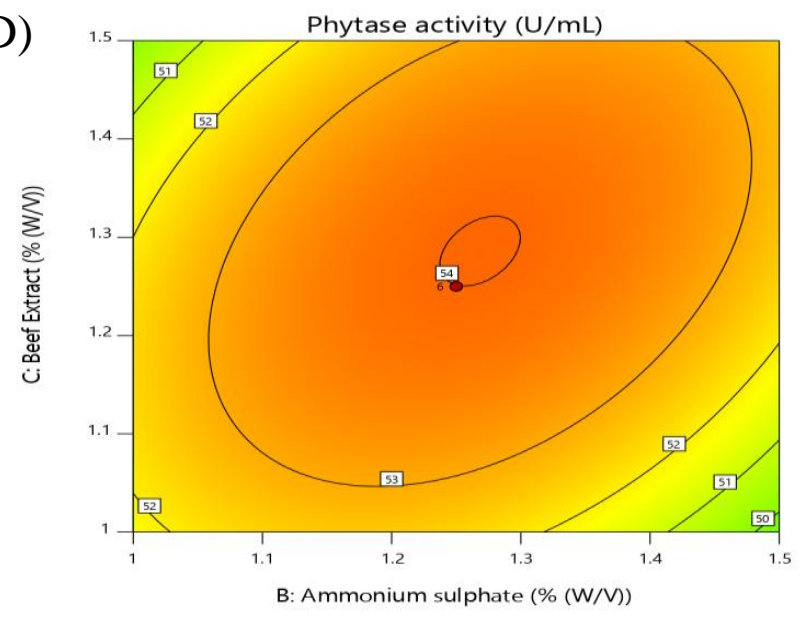

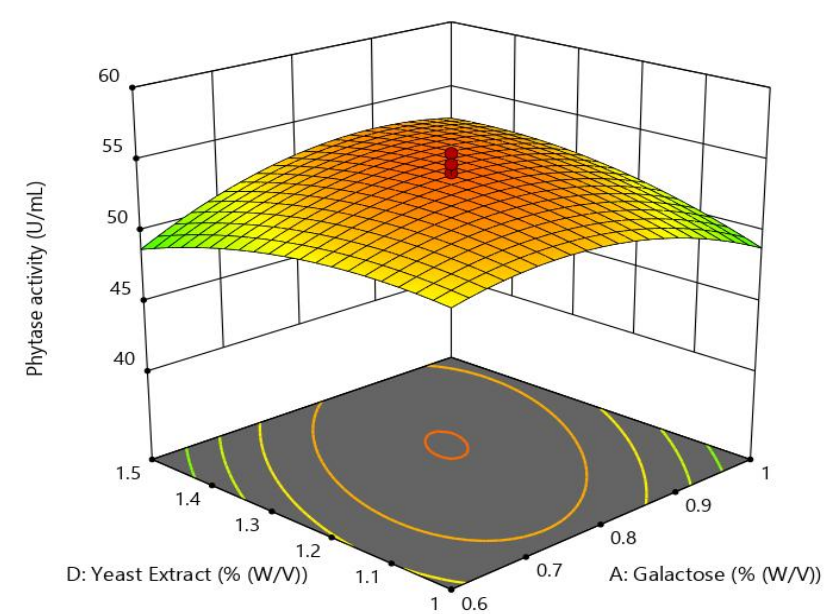

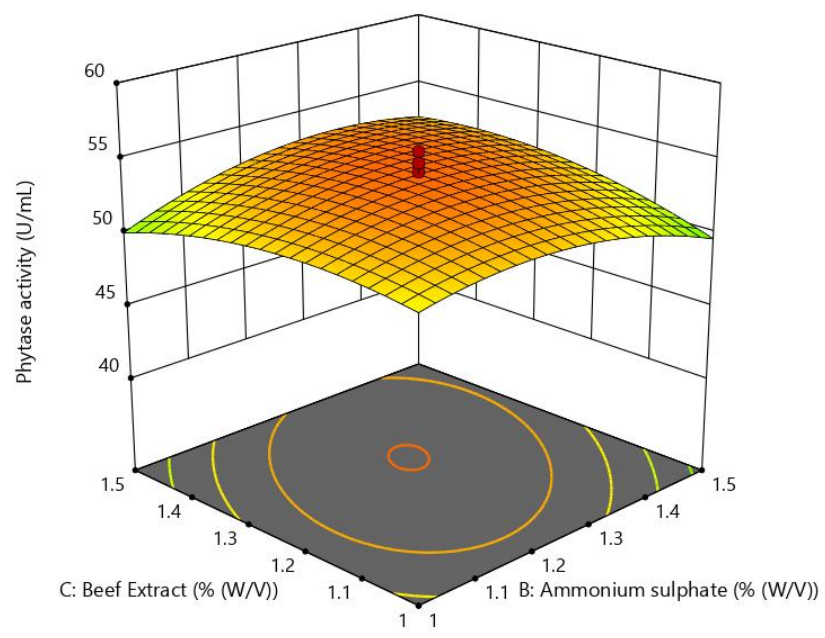


Fig.4 Elution profile of phytase on DEAE-Cellulose

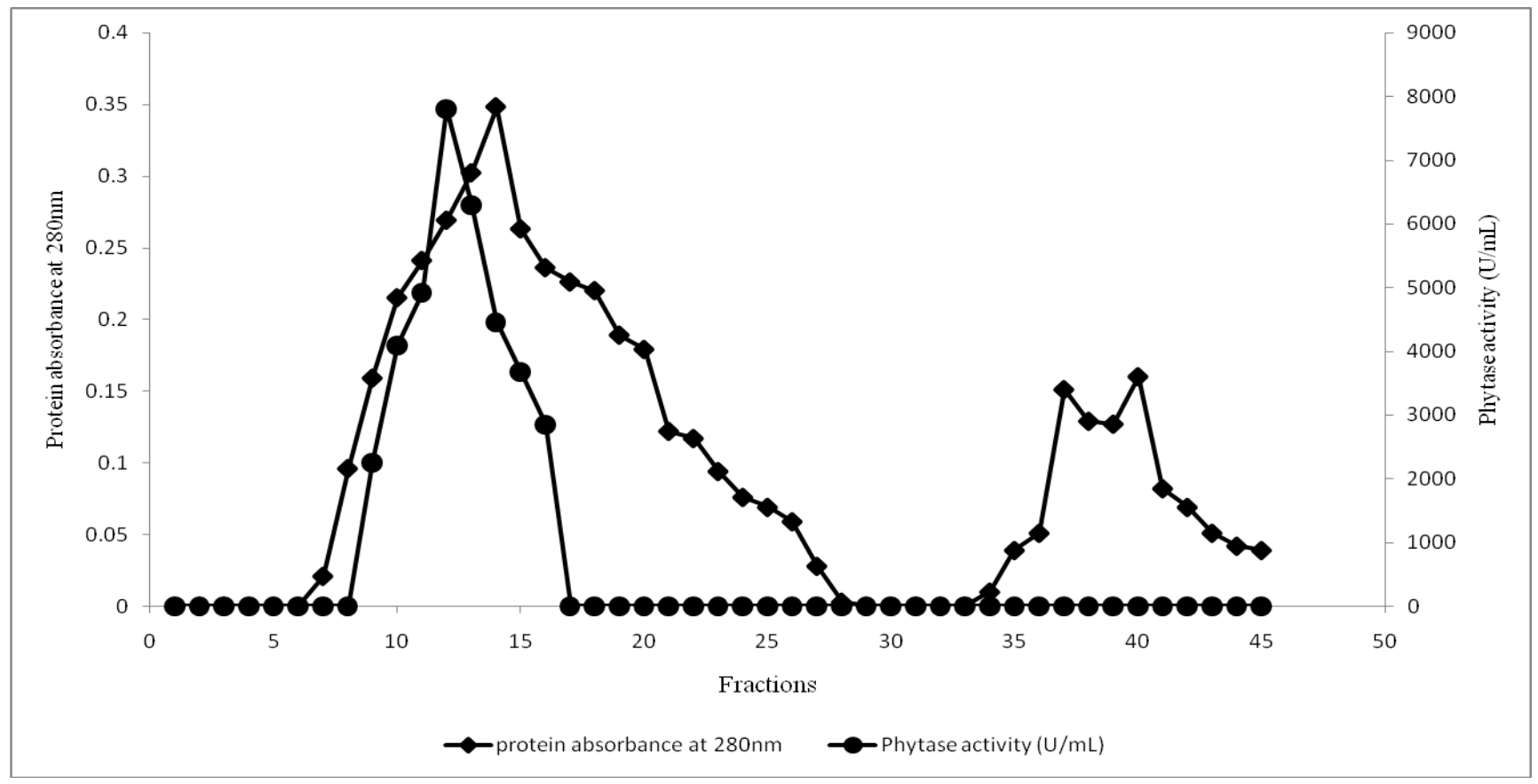

Fig.5 SDS-PAGE: A) Protein marker; B) DEAE-Cellulose elute

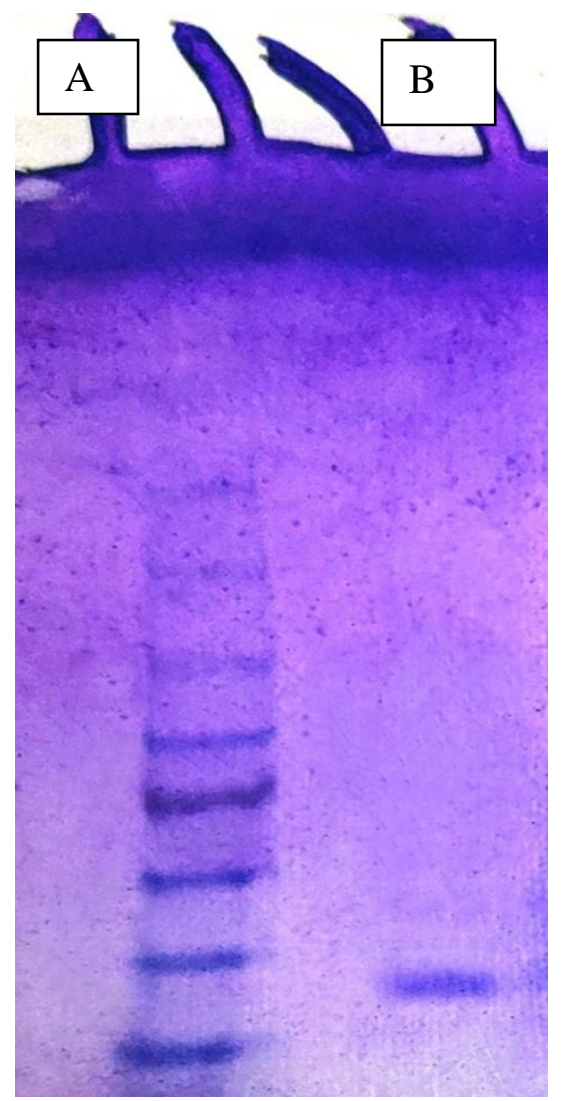


Fig.6 Effect of $\mathrm{pH}$ on purified phytase activity and stability

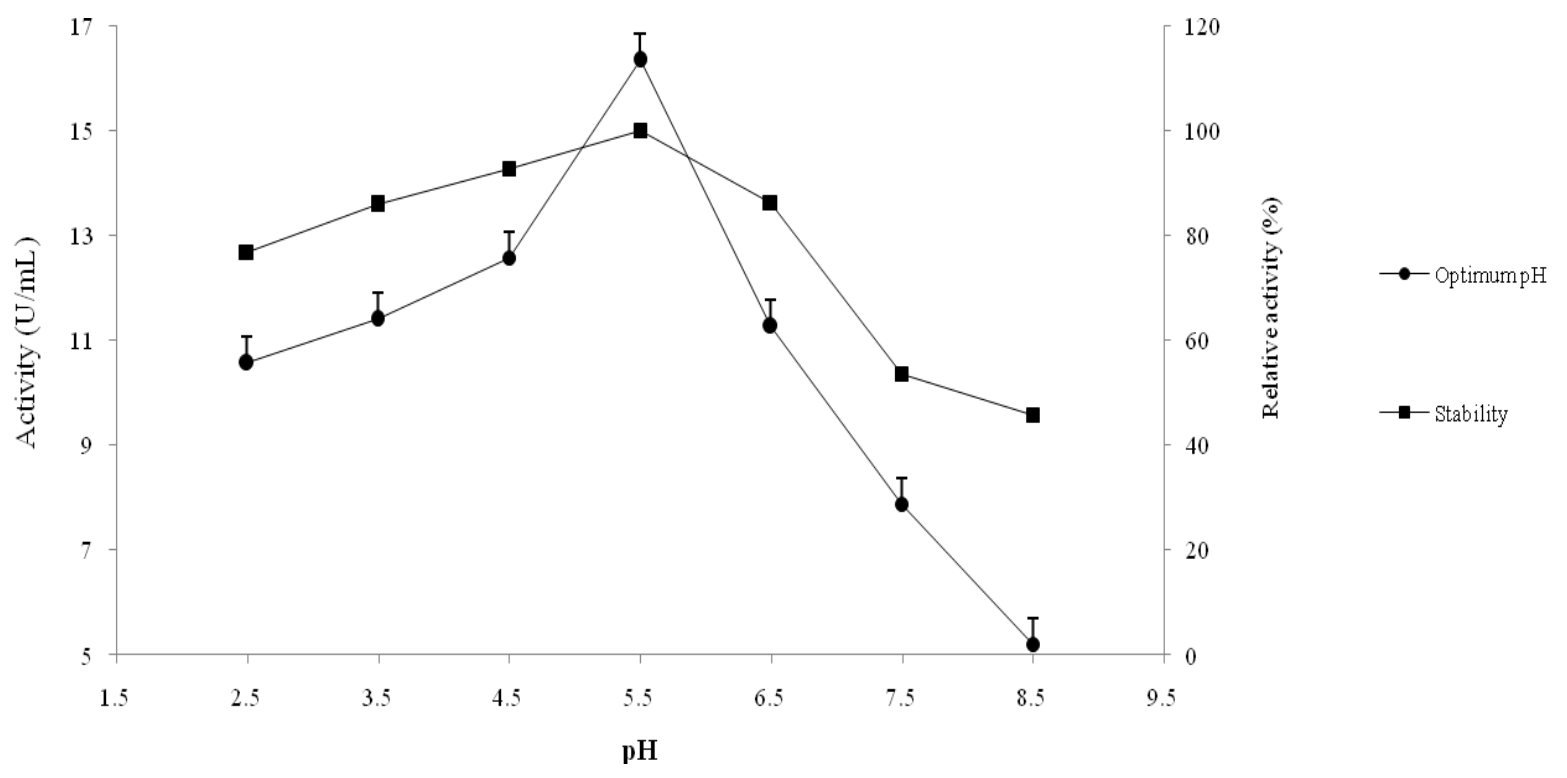

Fig.7 Effect of temperature on purified phytase activity and stability

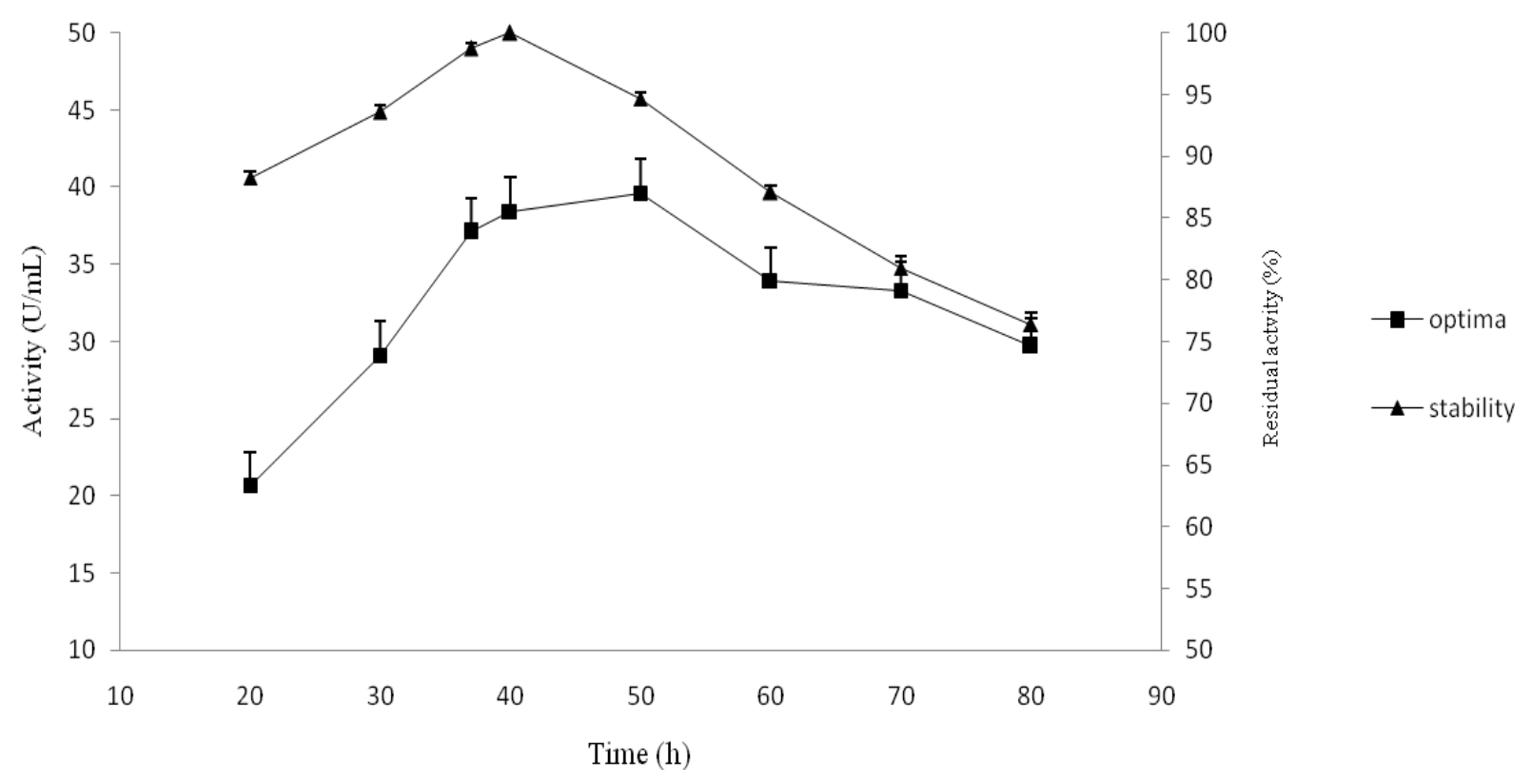


Fig.8 Kinetic parameter of enzyme phytase:

a) Michaelis-Menten curve; b) Lineweaver-Burk plot

a)

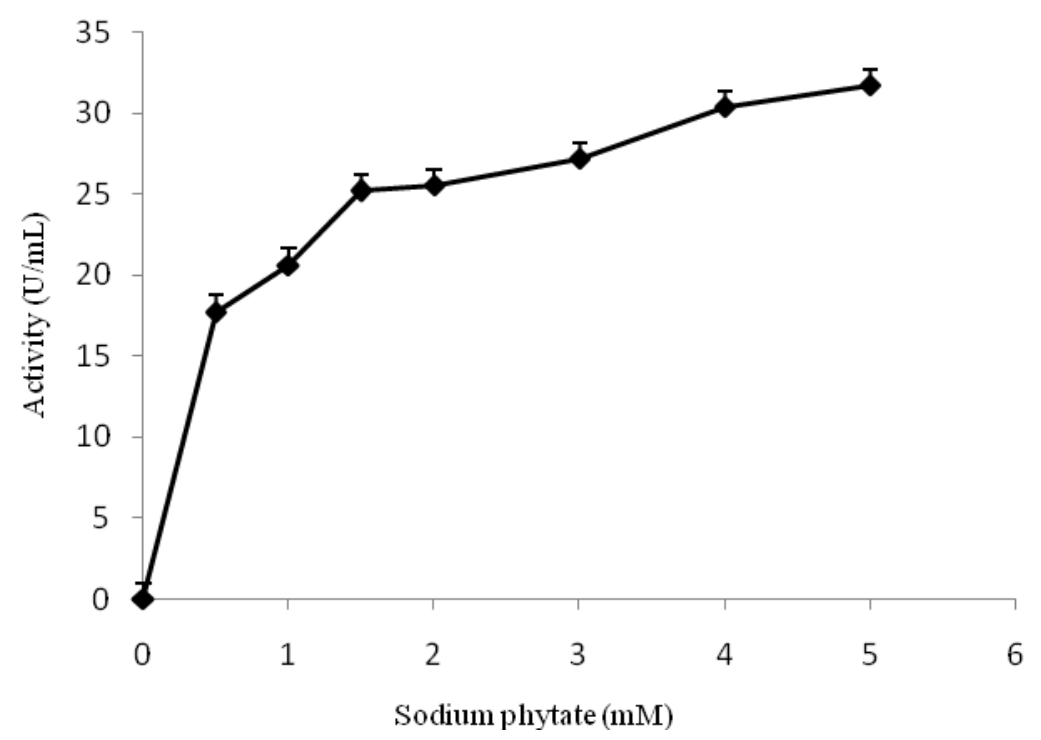

b)

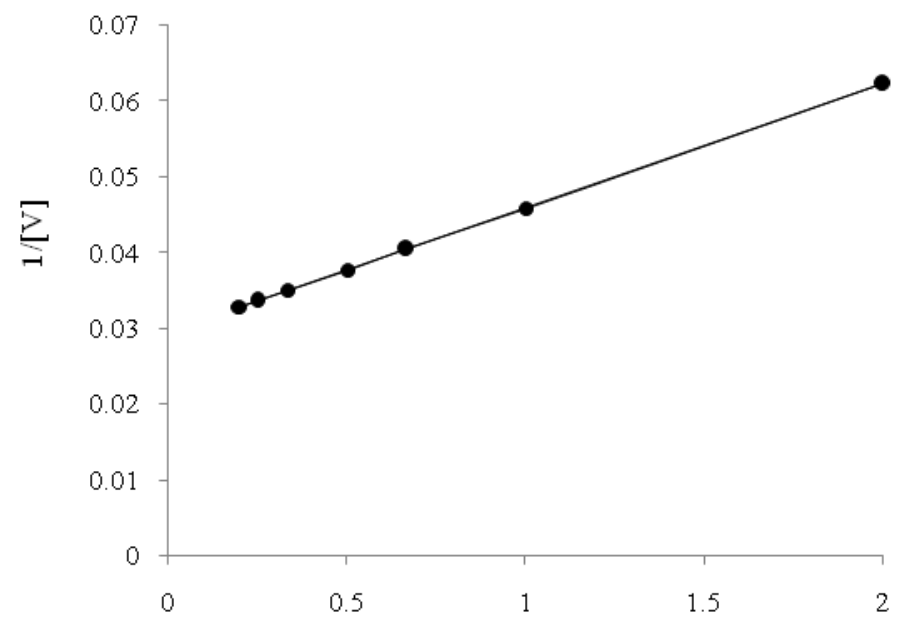

$1 /[S]$ 


\section{Temperature optima and stability}

The optimum temperature for purified phytase activity was found to be $40^{\circ} \mathrm{C}$ (Fig. 7 ) and the enzyme retained an activity of over $76 \%$ at a temperature range of 20 to $80^{\circ} \mathrm{C}$. The enzyme was stable at temperature below $50^{\circ} \mathrm{C}$ with a relative activity of more than $90 \%$. However, at temperature above $50^{\circ} \mathrm{C}$ partial loss of activity was observed.

This observation is in accordance to previous studies where scientist have also found that the optimum temperature for most phytase produced from Bacillus sp., Pseudomonas, Shigella sp was in the range of $40-50^{\circ} \mathrm{C}$ (Patki et al., 2015). As thermal stability of an enzyme is important for its application in feed industry and phytases produced from our isolate may be a good alternative to available enzymes due to its stability at high temperatures (Saribuga et al., 2014).

\section{Effect of metal ions on purified phytase enzyme activity}

Effect of various metal ions such as $\mathrm{Cu}^{2+}$, $\mathrm{Mg}^{2+}, \mathrm{Fe}^{2+}, \mathrm{Zn}^{2+}, \mathrm{Ca}^{2+}$ and $\mathrm{Mn}^{2+}$ on the purified phytase activity was examined using calcium phytate as the substrate.

The purified phytase enzyme activity was inhibited by these cations at both the concentration of $0.5 \mathrm{mM}$ and $1 \mathrm{mM}$. (Table 5) and corroborates results with earlier studies (Kim et al., 2015).

However, Shimizu (1992) have found that activity of extracellular phytase from $B$. subtilis (natto) N-77 strain was inhibited by the addition of EDTA, $\mathrm{Fe}^{2+}, \mathrm{Zn}^{2+}, \mathrm{Ca}^{2+}, \mathrm{Ba}^{2+}$, $\mathrm{Cu}^{2+}$, and $\mathrm{Al}^{3}$ suggesting that metal ions are not required for the functioning of enzyme as different organisms require different metal ions (Roy et al., 2012).

\section{Substrate specificity and Kinetic parameters}

The purified phytase has very narrow substrate specificity as it hydrolysed only phytic acid salts and showed highest activity towards sodium phytate. Phytase produced from E. coli has been reported to be highly specific for phytate whereas phytase from Aspergilus fumigates, Klebsiella pneumonia and $V$. volvacea were found to have broad specificity for phosphoryated substrate but relatively low specificity to phytate (Menezes-Blackburn, 2015). The results on varying substrate concentration revealed that the enzyme activity follows normal Michaelis-Menten curve. $K_{m}$ and $V_{\max }$ values from the Lineweavers-Burk Reciprocal plot were found to be $0.5455 \mathrm{mM}$ and $33.927 \mu \mathrm{mol} / \mathrm{min}$ (Fig 9). The lower $\mathrm{K}_{\mathrm{m}}$ values suggests higher affinity of substrate whereas higher $V_{\max }$ suggests a higher efficiency, although the $\mathrm{K}_{\mathrm{m}}$ of phytases from different organisms was reported to be in the range of 0.08 to $10 \mathrm{mM}$ showing variable affinity for different phosphorylated substrates (Parhamfar et al., 2015). Interstingly, phytase from $P$ acidilactici BNS5B has lower $K_{m}$ for sodium phytate suggesting its higher substrate affinity.

The data of present study indicated that by optimizing various physic-chemical parameters for the phytase production using OVAT followed by Plackett-Burman and Response surface methodology statistical methods enhanced the production of phytase from $0.59 \mathrm{U} / \mathrm{mL}$ to $55.53 \mathrm{U} / \mathrm{mL}$ leading to approximately 94 fold increase. Moreover, the purified enzyme showed high specific activity, substrate specificity, good $\mathrm{pH}$ profile and thermostability which could promote its industrial application as well as in human beings to enhance the bioavailability of minerals, but needs to be evaluated either clinically or experimentally. 


\section{Acknowledgment}

Financial assistance provided by University Grant Commission-Basic Scientific Research (F.25-1/2014-15(BSR)/7-261/2009), New Delhi, India, is highly acknowledged.

\section{References}

Almeida, F.N., Sulabo, R.C. and Stein, H. 2013. Effect of novel bacterial phytase expressed in Aspergillus oryzae on digestibility of calcium and phosphorous in diets fed to weanling or growing pigs. Journal of Animal Science and Biotechnology, 4:8-15.

Ashraf, M.A., Asif, M., Zaheer, A., Malik, A., Ali, Q. and Rasool, M. 2013. Plant growth promoting rhizobacteria and sustainable agriculture: a review. African Journal of Microbiological Reserve, 7:704-709.

Black, R.E., Victora, C.G., Walker, S.P., Bhutta, Z.A., Christian, P., de Onis, M., Ezzati, M., Mc Gregor, S.G., Katz, J., Martorell, R. and Uauy, R. 2013. Maternal and child undernutrition and overweight in lowincome and middle-income countries. Lancet, 382(9890):427-451.

Christian, P. and Stewart, C.P. 2010. The American Institute of Nutrition Maternal Micronutrient Deficiency, Fetal Development and the Risk of Chronic Disease. The Journal of Nutrition, 140:437-445.

El- Toukhy, N.M.K., Youssef, A.S. and Mikhail, M.G.M. 2013. Isolation, purification and characterization of phytase from Bacillus subtilis MJA. African Journal of Biotechnology, 12(20):2957-2967.

Feng, Q., Chen, W.D. and Wang, Y.D. 2018. Gut microbiota: An integral moderator in health and disease. Fronteirs in Microbiology, 9:151.

Gao, H., Liu, M., Liu, J., Dai, H., Zhoux, X., Liu, X., Zhou, Y., Zhang, W. and Zhang, L. 2009. Medium optimisation for the production of avermectin B1a by Streptomyces avermitilis 14-12A using response surface methodology. Bioresource Technology, 100:40124016.

Haefner, S., Knietsch, A., Scholten, E., Braun, J., Lohscheidt, M. and Zelder, O. 2005. Biotechnological application and production of phytases. Applied Microbiology and Biotechnology, 68:588-597.

Hayek, S.A. and Ibrahim, S.A. 2013. Current Limitations and Challenges with Lactic Acid Bacteria: A Review. Food and Nutrition Sciences, 4:73-87.

Kim, B.H., Lee, J.Y. and Lee, P.C.W. 2015. Purification, sequencing and evaluation of a divergent phytase from Penicillium oxalicum KCTC6440. The Journal of General and applied Microbiology, 61:117123.

Kumar, P. and Satyanarayana, T. 2007. Optimisation of culture variables for improving glycoamylase production by alginate-entrapped Thermoтисоr indicae-seudaticae using statistical methods. Bioresource Technology, 98:1252-1259.

Laemmli, U.K. 1970. Cleavage of structural proteins during the assembly of the head of bacteriophage T4. Nature 227:680-685.

Li, Y., Peng, X. and Chen, H. 2013. Comparative characterization of proteins secreted by Neurospora sitophila in solid-state and submerged fermentation. Journal of Bioscience and Bioengineering, 116:493-498.

Madsen, C.K. and Brinch-Pedersen, H. 2019. Molecular Advances on Phytases in 
Barley and Wheat. International Journal of Molecular Science, 20: 2459.

Menezes-Blackburn, D., Gabler, S. and Greiner, R. 2015. Performance of seven commercial phytases in an in vitro simulation of poultry digestive tract. Journal of Agricultural and Food Chemistry, 63:6142-6149.

Nam-Soon, O. and Man-Jin, I. 2009. Phytate degradation by Leuconostoc mesenteroides KC51 cultivation in soymilk. African Journal of Biotechnology, 8(13): 3023-3026.

Nielsen, M.M., Damstrup, M.L. and Hansen, A. 2008. An optimised microtiter plate method for characterisation of endogenous rye phytase under industrial rye bread making conditions. European Food Research and Technology, 227:1009-1015.

Parhamfar, M., Badoei-Dalfard, A., Khaleghi, M. and Hassanshahian, M. 2015. Purification and characterization of acidic, thermophilic phytase from a newly isolated Geobacillus stearothermophilus strain DM12. Progress in Biological Sciences, 5(1):61-73.

Patki, J.M., Singh, S. and Mehta, S. 2015.Partial purification and characterization of phytase from bacteria inhabiting the Mangroves of the western coast of India International journal of current microbiology and applied sciences, 4(9):156-169.

Plackett, R.L. and Burman, J.P. 1946. The design of optimum multifactorial experiments. Biometrika 37:305-325.

Qvirist, L., Vorontsov, E., Vilg, J.V. and Andlid T. 2017. Strain improvement of Pichia kudriavzevii TY13 for raised phytase production and reduced phosphate repression. Microbiology and Biotechnology, 10:341-353.

Rasul, M., Yasmin, S., Suleman, M., Zaheer, A., Reitz, T., Tarkka, M.T., Islam, E. and Mirza, M.S. 2019. Glucose dehydrogenase gene containing phosphobacteria for biofortification of Phosphorus with growth promotion of rice. Microbiological Reserves, 223:112.

Raghavendra, P. and Halami, P.M. (2009). Screening, selection and characterization of phytic acid degrading lactic acid bacteria from chicken intestine. Int $J$ Food Microbiol 133: 129-134.

Roy, M.P., Poddar, M., Singh, K.K. and Ghosh, S. 2012. Purification, characterization and properties of phytase from Shigella sp. CD2. Indian Journal of Biochemistry and Biophysics, 49:266-271.

Saravanamuthu, R. 2010. Industrial exploitation of microorganisms. Edition: Illustrated. I.K. International Publishing House Pvt Ltd. India.

Saribuga, E., Nadaroglu, H., Dikbas, N., Senol, M. and Cetin, B. 2014. Purification and characterization of phytase enzyme from Lactobacillus plantarum bacteria and determination of its kinetic properties. African Journal of Biotechnology, 13(23):2273-2278.

Shah, P.C., Kumar, V.R., Dastager, S.G. and Khire, J.M. 2017. Phytase production by Aspergillus niger NCIM 563 for a novel application to degrade organophosphorous pesticides. $A M B$ express 7:66.

Shimizu, M. 1992. Purification and characterization of phytase from Bacillus subtilis (natto) N-77. Bioscience, Biotechnology, and Biochemistry, 56:1266-1269. 
Singh, B. and Satyanarayan, T. 2006. A marked enhancement in phytase production by a thermophilic mould Sporotrichum thermophile using statistical design in a cost effective cane molasses medium. Journal of applied microbiology. 101: 344-352.

Singh, N.K., Joshi, D.K. and Gupta, R.K. 2013. Isolation of phytase producing bacteria and optimisation of phytase production parameters. Jundishapur Journal of Microbiology, 6(5):e6419.

Sreedevi, S. and Reddy, B.N. 2013. Identification of phytase producing bacteria $\mathrm{C} 43$ isolated from cattle shed soil samples of Hyderabad, A.P. Helix, 1:238-242.

\section{How to cite this article:}

Bhawna Sharma and Geeta Shukla 2019. Optimisation, Purification and Characterisation of Phytase from Isolated Probiotic Pediococcus acidilactici BNS5B. Int.J.Curr.Microbiol.App.Sci. 8(09): 2060-2081. doi: https://doi.org/10.20546/ijcmas.2019.809.238
Tungala, A, Narayanan, K.A. and Muthuraman, M.S. 2013. Isolation of phytase producing bacteria from poultry faeces and optimization of culture conditions for enhanced phytase production. International Journal of Pharmacy and Pharmaceutical Sciences, 5(4):264269.

Wood, B. J. B. and Holzapfel, W. H. 1995. "The Genera of Lactic Acid Bacteria in the Lactic acid Bacteria," In: B. J. B. Wood and W. H. Holzapfel Eds., The Genera of Lactic Acid Bacteria Blackie, Academic and Professional, London, 1995, pp. 398. 